(c) American Dairy Science Association, 2005.

\title{
Selection Indices in Holstein Cattle of Various Countries
}

\author{
F. Miglior, ${ }^{1,2}$ B. L. Muir, ${ }^{2}$ and B. J. Van Doormaal ${ }^{2}$ \\ ${ }^{1}$ Agriculture and Agri-Food Canada - Dairy and Swine Research and Development Centre \\ Lennoxville, QC, Canada \\ ${ }^{2}$ Canadian Dairy Network, Guelph, ON, Canada
}

\begin{abstract}
Fifteen countries, based on geographical representation, Interbull membership, and size of progeny testing programs, provided a brief description of national selection index and top bull listings from August 2003. Individual traits included in each selection index were grouped into 3 components as they related to production, durability, and health and reproduction. The relative emphasis for each component within the selection index, as well as the number of common bulls among top listings were compared across countries. Average relative emphasis for production, durability, and health and reproduction, across all countries, was $59.5,28$, and $12.5 \%$, respectively. The main difference between selection indices in various countries was the relative emphasis on production. Overall, the Danish S-Index had the most balanced emphasis across the 3 components, with $34 \%$ on production, $29 \%$ on durability, and $37 \%$ on health and reproduction. Broadening of breeding goals through recent changes to selection indices decreased the similarities of top bull listings across the various countries, with a slightly greater commonality among sires of top bulls.
\end{abstract}

(Key words: selection index, bull ranking, international dairy)

Abbreviation key: Interbull = International Bull Evaluation Service.

\section{INTRODUCTION}

For many years, most selection indices worldwide focused on increasing milk production. National selection indices were based on improving milk yield and gradually shifted toward improving protein yield and, outside North America, toward increasing fat and especially protein content. This was true for most countries with the exception of the Scandinavian countries, whose selection indices also included health and repro-

Received June 8, 2004.

November 18, 2004

Corresponding author: Filippo Miglior; e-mail: miglior@cdn.ca. duction, and North American countries, whose selection indices included conformation together with production. In the last $5 \mathrm{yr}$, there has been a growing interest in broadening selection indices to include functional traits such as reproduction and health. Main reasons for this shift were quota-based milk marketing systems, price constraints, or both, together with increasing producer and consumer concerns associated with the observed deterioration of the health and reproduction of dairy cows. Labor costs have increased relatively more than milk price in some countries. Several studies have shown that selection for production alone causes negative effects on udder health (Heringstad et al., 2003) and reproductive performance (Veerkamp et al., 2001; Haile-Mariam et al., 2003; Kadarmideen et al., 2003).

A decade ago, Leitch (1994) reported the relative emphasis on traits in selection indices from various countries. VanRaden (2002) reported the relative emphasis on traits in the US Net Merit formula in 1994 for comparison. Six selection indices placed $100 \% \mathrm{em}-$ phasis on production (Germany, France, Great Britain, Israel, the Netherlands, and New Zealand) and 4 indices placed approximately one-third emphasis on longevity and conformation traits in addition to production (US TPI and Net Merit, Canada, and Italy). The Danish S-Index (28\%) and the US Net Merit (6\%) were the only national selection indices that placed some emphasis on health and reproduction. Denmark placed relatively little emphasis on production (30\%) compared with other countries, but also placed emphasis on durability $(42 \%)$ and health and reproduction (28\%), for a balanced selection index. Since 1994, several changes to national selection indices have been implemented and it is therefore of interest to assess changes in breeding goals in various countries over time.

Inbreeding levels have increased in Holstein populations worldwide and annual rate of inbreeding accelerated until the year 2000, especially in North American populations (Miglior, 2000). In the last $5 \mathrm{yr}$, inbreeding rates have slowed in North America (AIPL, 2004; CDN, 2004), France (S. Mattalia, personal communication, 2004), and Italy (S. Biffani, personal communi- 
cation, 2004), whereas annual rates have not changed in Great Britain (Kearney et al., 2004). Lower rates of inbreeding are expected over the long term, because a broader range of traits is considered in different selection indices. Differences among national top bull rankings may help explain the likelihood that different bulls are being selected worldwide.

The main objective of this study was to provide an overview and compare national selection indices currently used in various countries. A second aim was to quantify differences in top bull listings worldwide, as well as the commonality of their sires.

\section{MATERIALS AND METHODS}

Fifteen countries provided data for this study. Countries were chosen based on geographical representation, International Bull Evaluation Service (Interbull) membership, and size of progeny testing programs. Each national genetic evaluation center provided a brief description of their national selection index, including the relative emphasis of each trait in the overall index. Relative emphasis was expressed as a percentage and was computed as the economic weight divided by the breeding value standard deviation.

Traits from national selection indices were separated into 3 components. The first, production, was to recognize its contribution to higher revenue. Durability, the second component, was meant to include traits that contributed to increased profit due to longer herd life of cows. The third component, health and reproduction, was meant to include traits that reduce the cost of production, which are mainly traits related to health and reproductive performance. Therefore, the 3 components included the following traits: (i) production (milk, fat, and protein yield, fat and protein percentage); (ii) durability (longevity, body size, overall udder, feet and legs, final score, other conformation traits, milking temperament, and meat quality); and (iii) health and reproduction (udder health, calving ease, and milking speed). The durability component encompassed all remaining traits in each national selection index that were not directly related to dairy production or to health and reproduction. All conformation traits and conformation composites in national selection indices were included in the durability component. As an exception, specific linear conformation traits were included in the health and reproduction component because Canada, the Netherlands, and Denmark placed direct emphasis on udder health using a combination of these linear conformation traits, as well as milking speed and SCS. All other countries evaluated udder health as SCS only. Other conformation traits in the durability component included overall rump and dairy character.

Each country provided its August 2003 official top100 bull listing based on their national selection index. If this list was compiled based on minimum requirements of reliability or number of daughters, a second list was provided without such constraints. The United States and Great Britain each provided 2 national selection indices. All other countries provided a single index. Top-100 bull listings for national selection indices were based on bull breeding values originating from 3 different sources depending on number of local daughters or reliability level and availability of Interbull evaluations for a given trait: 1) domestic breeding values are used for all traits for bulls with a sufficient number of local daughters or sufficient degree of reliability; 2) Interbull breeding values are used for bulls without local daughters or with an insufficient number of local daughters, degree of reliability, or both; and 3) breeding values for traits not included in Interbull evaluations are based on conversion formulas, prediction equations, pedigree index, or breed average for bulls without local daughters. Conversion formulas were linear regressions to convert national evaluations from one country to the base and scale of another country. Prediction equations were multiple regressions to predict a trait not included in Interbull evaluations using national complete data. National policies regarding use of international breeding values are summarized on the Interbull Web site (Interbull, 2004) and each country is responsible for deciding which conversion strategy to adopt in all 3 options. However, most countries do not provide information about which conversion strategy they use for those traits that are not included in Interbull evaluations.

Top-100 bull listings for national selection indices were compared to determine the number of common bulls present in various country pairs. Sires of top bulls were also identified and compared across countries. Differences in selection indices across countries would be expected to lower the number of top bulls in common or the number of sires of top bulls in common.

In a second analysis, breeding values computed by Interbull in August 2003 were used to determine the top-100 bull list for protein yield, overall udder conformation, and SCS in each country. Again, bull listings were compared to determine the number of common bulls present in various countries. A summary of genetic correlations between countries used in the Interbull November 2003 routine evaluations for protein yield, overall udder, and SCS were reported to assist with interpretation of results. 


\section{RESULTS AND DISCUSSION}

\section{National Selection Indices}

Table 1 shows the relative emphasis on traits in national selection indices in August 2003. Based on information from Table 1, differences among countries are shown in Figure 1. Average relative emphasis for production, durability, and health and reproduction, across all countries, was $59.5,27.9$, and $12.6 \%$, respectively.

The main difference between selection indices in various countries was the relative emphasis on production. Israel placed the largest emphasis on production with $80 \%$, whereas Denmark placed the lowest at $34 \%$. Other indices with large emphasis on production were the British PLI and the Japanese NTP (both 75\%). With the exception of Denmark, all countries placed at least 50\% emphasis on the production component.

The TOP index, one of 2 indices used in Great Britain, placed the largest relative emphasis on durability (42\%), followed closely by the US TPI (41\%), the German RZG (40\%), the Canadian LPI (38\%), and the Spanish ICO (38\%). Israel did not place any direct emphasis on the durability component. Other indices with a low relative emphasis on durability were the Australian APR (16.5\%) and the British PLI (20\%).

The Danish S-Index placed the largest relative emphasis on the health and reproduction component (37\%), followed by the French ISU (25\%). The US Net Merit and the Israeli PD01 both placed 20\% emphasis on this component. The Japanese NTP did not have any direct emphasis on the health and reproduction component, and Spain placed only 3\% emphasis on this component. Overall, the Danish S-Index had the most balanced emphasis across the 3 components, with $34 \%$ on production, $29 \%$ on durability, and $37 \%$ on health and reproduction.

Within the production component, the Japanese NTP had the largest emphasis on protein yield with $55 \%$, followed by the Israeli PD01 (51\%), and the British PLI (49\%). Lowest emphasis for protein yield was observed for the Danish S-Index (20.4\%), followed by the German RZG (26\%), and the Swiss ISEL (27\%). The US Net Merit index had the largest emphasis for fat yield (22\%), whereas the British TOP had the lowest (6\%). North America and Japan did not put any direct emphasis on fat or protein percentages and did not emphasize greater fat or protein percentages indirectly through negative emphasis on milk volume. All other indices had a positive relative emphasis on the components either directly (ISEL, RZG, PFT, and ISU) or through a negative weight on milk yield (8 remaining indices). The Spanish ICO was an exception as it had positive weight on both milk yield and protein percentage.

Within the durability component, the Dutch DPS had the largest emphasis on longevity with $26 \%$, followed by the German RZG (25\%), and the Irish EBI (23\%). No direct emphasis for longevity was reported for the Israeli PD01 and the Japanese NTP. On average, conformation traits provided the largest contribution to the durability component. The British TOP had the largest emphasis (40\%), with $18 \%$ on overall udder, $14 \%$ on feet and legs, and $8 \%$ on body size. Canada had the second largest emphasis on conformation traits with $30.4 \%$ (15.2\% on overall udder, $11.4 \%$ on feet and legs, and $3.8 \%$ on body size). Five selection indices put positive emphasis on traits related to body size, and 4 other indices put a negative weight. The New Zealander BW placed the largest emphasis on body weight $(-19 \%)$.

Udder health and female fertility dominated the health and reproduction component. In most indices, SCS (an indicator trait for mastitis resistance) was the only trait contributing to udder health, with 3 exceptions: Canada, the Netherlands, and Denmark. The Canadian udder health index was based on SCS $(60 \%)$, udder depth $(-30 \%)$, and milking speed $(10 \%)$. The Dutch udder health index was a combination of SCS, udder depth, fore udder attachment, teat length, and milking speed. The Danish udder health index was based on clinical mastitis, SCS, udder depth, udder support, and dairy form, with a combined emphasis of $14 \%$ on the Danish S-Index. The Danish S-Index had also a $6 \%$ emphasis on milking speed and $2 \%$ on resistance to other diseases.

The French ISU had the largest emphasis on female fertility (12.5\%), followed by the Danish S-Index and the Israeli PD01 (both 9\%). Several indices (7) did not have any direct emphasis on female fertility. Only 3 indices put some weight on calving ease $(8,6$, and $4 \%$ for the Dutch DPS, Danish S-Index, and US Net Merit, respectively). No index placed any emphasis on stillbirth, even though increasing stillbirth rates have been reported in some Holstein populations, namely the Netherlands (Harbers et al., 1999), United States (Meyer et al., 2001), and Denmark (Hansen et al., 2004).

\section{Bull Rankings in Various Countries}

Table 2 has averages and ranges of Interbull genetic correlations for protein yield, overall udder, and SCS among countries considered in this study (November 2003 evaluations, Interbull, 2003a,b,c). Ireland and Israel were not included in Interbull evaluations for overall udder; and Spain, Ireland, and New Zealand 
Table 1. Relative emphasis on traits in national selection indices in August 2003.

\begin{tabular}{|c|c|c|c|c|c|c|c|c|c|c|c|c|c|c|c|c|c|}
\hline \multirow[b]{2}{*}{ Country } & \multirow[b]{2}{*}{ Index } & \multicolumn{5}{|c|}{ Production } & \multicolumn{7}{|c|}{ Durability } & \multicolumn{4}{|c|}{ Health and reproduction } \\
\hline & & $\begin{array}{l}\text { Milk } \\
\text { yield }\end{array}$ & $\begin{array}{l}\text { Fat } \\
\text { yield }\end{array}$ & $\begin{array}{l}\text { Protein } \\
\text { yield }\end{array}$ & $\begin{array}{l}\text { Fat } \\
\%\end{array}$ & $\begin{array}{l}\text { Protein } \\
\%\end{array}$ & Longevity & $\begin{array}{l}\text { Body } \\
\text { size }\end{array}$ & $\begin{array}{l}\text { Overall } \\
\text { udder }\end{array}$ & $\begin{array}{l}\text { Feet } \\
\& \text { legs }\end{array}$ & $\begin{array}{l}\text { Final } \\
\text { score }\end{array}$ & $\begin{array}{l}\text { Milking } \\
\text { temp. }\end{array}$ & Other & $\begin{array}{l}\text { Udder } \\
\text { health }\end{array}$ & Fertility & $\begin{array}{l}\text { Calving } \\
\text { ease }\end{array}$ & Other \\
\hline Australia & APR & -18.6 & 12.0 & 36.3 & - & - & 8.5 & -4.0 & - & - & - & 4.0 & - & 5.2 & 8.2 & - & $3.2^{1}$ \\
\hline Canada & LPI & - & 14.3 & 42.7 & - & - & 7.6 & 3.8 & 15.2 & 11.4 & - & - & - & 5.0 & - & - & - \\
\hline Switzerland & ISEL & - & 14.0 & 27.0 & 3.0 & 9.0 & 7.0 & 4.8 & 9.6 & 4.8 & - & - & $4.8^{2}$ & 1.0 & 6.0 & - & - \\
\hline Germany & RZG & - & 9.0 & 26.0 & 5.0 & 1.0 & 25.0 & 3.0 & 6.0 & 3.7 & - & - & $2.3^{3}$ & 5.0 & 5.0 & - & - \\
\hline Denmark & S-Index & -3.4 & 1.2 & 2.4 & - & - & 6.0 & -2.0 & 9.0 & 5.0 & - & 2.0 & $5.0^{4}$ & 14.0 & 9.0 & 6.0 & $8.0^{5}$ \\
\hline Spain & ICO & 12.0 & 12.0 & 32.0 & - & 3.0 & 3.0 & - & 16.0 & 1.0 & 9.0 & - & - & 3.0 & - & - & - \\
\hline France & ISU & - & 9.5 & 35.5 & 2.5 & 2.5 & 12.5 & 2.1 & 8.3 & 1.5 & - & - & $1.5^{6}$ & 12.5 & 12.5 & - & - \\
\hline Great Britain & PLI & -16.4 & 9.5 & 49.1 & - & - & 15.0 & - & - & 5.0 & - & - & - & 5.0 & - & - & - \\
\hline Great Britain & TOP & -1.9 & 6.3 & 32.8 & - & - & 2.0 & 8.0 & 18.0 & 14.0 & - & - & - & 8.0 & - & - & - \\
\hline Ireland & EBI & -19.0 & 8.0 & 42.0 & - & - & 23.0 & - & - & - & - & - & - & - & 8.0 & - & - \\
\hline Israel & PD01 & -11.0 & 18.0 & 51.0 & - & - & - & - & - & - & - & - & - & 11.0 & 9.0 & - & - \\
\hline Italy & PFT & - & 12.0 & 42.0 & 2.0 & 3.0 & 8.0 & - & 13.0 & 6.0 & 4.0 & - & - & 1.0 & - & - & - \\
\hline Japan & NTP & - & 2.3 & 54.7 & - & - & - & - & 21.3 & 3.7 & - & - & - & - & - & - & - \\
\hline The Netherlands & DPS & -17.0 & 7.0 & 34.0 & - & - & 26.0 & - & - & - & - & - & - & 4.0 & 4.0 & 8.0 & - \\
\hline New Zealand & BW & -17.0 & 8.0 & 41.0 & - & - & 5.0 & -19.0 & - & - & - & - & - & - & 1.0 & - & - \\
\hline United States & Net Merit & - & 22.0 & 33.0 & - & - & 11.0 & -3.0 & 7.0 & 4.0 & - & - & - & 9.0 & 7.0 & 4.0 & - \\
\hline United States & TPI & - & 18.0 & 36.0 & - & - & 11.0 & - & 1.0 & 5.0 & 15.0 & - & - & 5.0 & - & - & - \\
\hline
\end{tabular}

${ }^{1}$ Milking speed.

${ }^{2}$ Overall rump (2.4\%) and dairy character $2.4 \%$.

${ }^{3}$ Dairy character.

${ }^{4}$ Meat quality.

${ }^{5}$ Milking speed (6\%) and other health traits $(2 \%)$.

${ }^{6}$ Overall rump. 


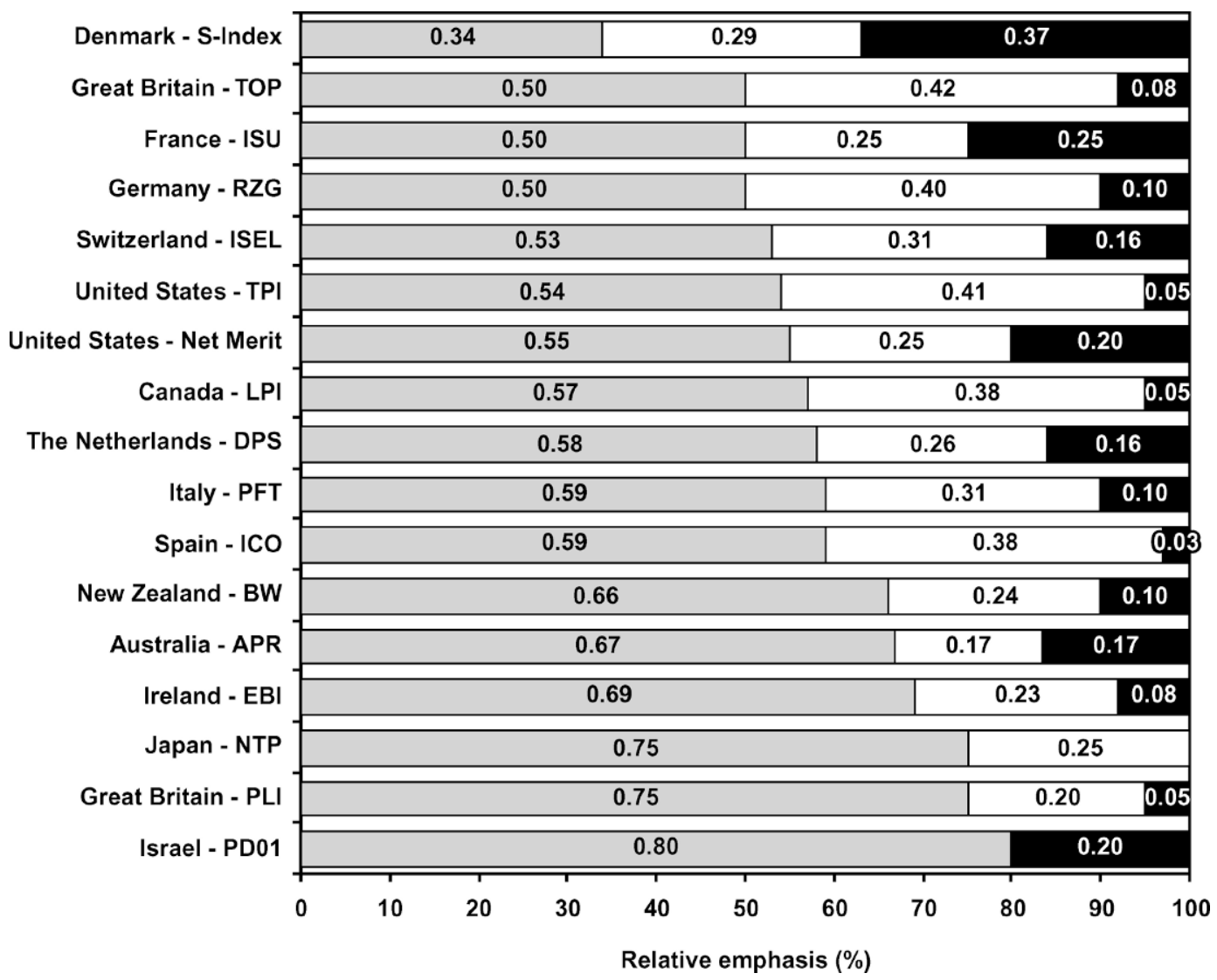

Figure 1. Relative emphasis on production (gray), durability (white), and health and reproduction (black) components in selection indices of countries in August 2003.

Table 2. Averages and ranges of across-country genetic correlations and number of bulls in common with other countries from top-100 bull listings for protein yield, overall udder, and SCS (Interbull, November 2003).

\begin{tabular}{|c|c|c|c|c|c|c|c|c|c|c|c|c|}
\hline & \multicolumn{4}{|c|}{ Protein yield } & \multicolumn{4}{|c|}{ Overall udder } & \multicolumn{4}{|c|}{ SCS } \\
\hline & \multicolumn{2}{|c|}{ Genetic correlation } & \multicolumn{2}{|c|}{ Common bulls } & \multicolumn{2}{|c|}{ Genetic correlation } & \multicolumn{2}{|c|}{ Common bulls } & \multicolumn{2}{|c|}{ Genetic correlation } & \multicolumn{2}{|c|}{ Common bulls } \\
\hline & Average & Range & Average & Range & Average & Range & Average & Range & Average & Range & Average & Range \\
\hline Australia & 0.80 & $0.77-0.90$ & 43 & $31-67$ & 0.68 & $0.48-0.83$ & 45 & $30-54$ & 0.81 & $0.55-0.91$ & 49 & $37-57$ \\
\hline Canada & 0.89 & $0.78-0.95$ & 62 & $32-74$ & 0.86 & $0.68-0.96$ & 65 & $48-88$ & 0.91 & $0.91-0.91$ & 62 & $41-78$ \\
\hline Switzerland & 0.87 & $0.78-0.90$ & 60 & $41-73$ & 0.87 & $0.66-0.96$ & 67 & $44-88$ & 0.90 & $0.77-0.96$ & 68 & $49-86$ \\
\hline Germany & 0.87 & $0.77-0.91$ & 58 & $33-84$ & 0.83 & $0.72-0.93$ & 59 & $48-81$ & 0.87 & $0.78-0.95$ & 61 & $47-78$ \\
\hline France & 0.89 & $0.79-0.93$ & 62 & $45-76$ & 0.78 & $0.48-0.91$ & 55 & $30-74$ & 0.90 & $0.74-0.96$ & 69 & $53-86$ \\
\hline Great Britain & 0.89 & $0.82-0.94$ & 66 & $51-78$ & 0.82 & $0.67-0.92$ & 59 & $49-72$ & 0.88 & $0.70-0.97$ & 68 & $44-90$ \\
\hline Ireland & 0.87 & $0.83-0.91$ & 60 & $50-71$ & & & & & & & & \\
\hline Israel & 0.85 & $0.78-0.87$ & 66 & $43-79$ & & & & & 0.75 & $0.55-0.91$ & 56 & $40-65$ \\
\hline Italy & 0.87 & $0.77-0.95$ & 57 & $31-72$ & 0.87 & $0.68-0.95$ & 66 & $44-89$ & 0.83 & $0.75-0.91$ & 47 & $35-58$ \\
\hline Japan & 0.88 & $0.77-0.93$ & 64 & $42-80$ & 0.84 & $0.72-0.93$ & 58 & $41-78$ & 0.85 & $0.68-0.94$ & 57 & $35-73$ \\
\hline The Netherlands & 0.89 & $0.77-0.95$ & 62 & $43-76$ & 0.83 & $0.72-0.93$ & 58 & $48-81$ & 0.89 & $0.77-0.97$ & 68 & $47-90$ \\
\hline
\end{tabular}


were not included in Interbull evaluations for SCS. Average genetic correlations between the concerned countries were $0.87,0.82$, and 0.86 for protein yield, overall udder, and SCS, respectively. Genetic correlations ranged from 0.77 to $0.95,0.48$ to 0.96 , and 0.55 to 0.97 for protein yield, overall udder, and SCS, respectively. Genetic correlations significantly lower than unity yielded a low average number of common bulls in top-100 lists for all 3 traits (Table 2). For protein yield, the average number of common bulls was 60, ranging from 31 to 84. Australia and New Zealand had the lowest average number of common bulls with 43 and 48 , respectively, mainly due to the low genetic correlations with other countries. Overall udder and SCS had similar numbers of common bulls.

The number of common bulls decreased when top bull lists for national selection indices were compared (Table 3, below diagonal). The largest number of common bulls was within country between the British PLI and TOP (69) and between the US Net Merit and TPI (54). A small number of common bulls among Great Britain and the United States listings clearly showed the isolated effect of differences in selection indices, because genetic correlations within country for individual traits is equal to 1 . Excluding within-country comparisons in Great Britain and the United States, the largest number of common bulls was between the Canadian LPI and US TPI, and between the German RZG and the Danish S-Index, both at 46 common bulls. The selection index with the largest number of bulls in common with the other indices was the US TPI with an average of 25.1 bulls in common, followed by the Canadian LPI with 24.6 common bulls. Australia, New Zealand, and Ireland, 3 countries where grazing systems are commonplace, registered the lowest average number of common bulls with $2.7,3.2$, and 8.7 , respectively.

Bulls in top-100 lists are different among countries because of differences among national selection indices, genetic correlations lower than unity, and variable reliability of single bulls across countries. Many selection indices include traits for which an Interbull evaluation is not yet available (longevity, calving ease, fertility, and milking speed, for example). National genetic evaluation units try to overcome this problem and use various strategies of conversion as described in the previous section. Furthermore, broadening of selection indices that give relatively more weight to low heritability traits (longevity, health and reproduction) compared with higher heritability traits (production and conformation) has contributed to the decreased number of common bulls among national selection indices. The relative importance of domestic daughters in explaining international breeding values

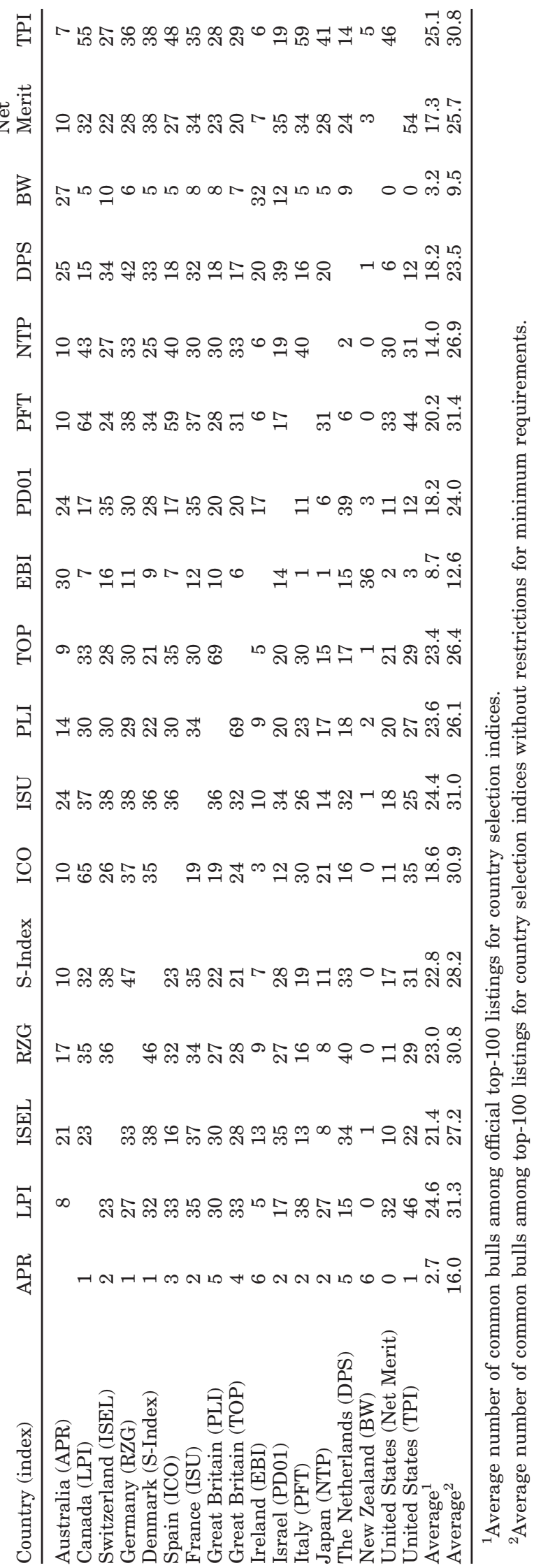


increases with decreasing heritability (Klei et al., 1999). The latter reason is exacerbated by the fact that most bulls in top-100 lists are recently proven bulls, with only domestic daughters.

Leitch (1994) reported a relatively high similarity among top bull listings across countries with a rank correlation greater than 0.88 . At that time, Interbull evaluations were not yet available and most countries focused entirely on production. Bull comparisons were based on simple conversion formulas that did not properly account for genotype by environment interaction (Goddard, 1985; Wilmink et al., 1986). Conversion formula methodology did not allow for reranking across countries for the same traits, and differences in top bull listings were solely based on differences in selection indices. In 1995, the Interbull Center started using the MACE procedure (Schaeffer, 1994) to compute international evaluations with estimated genetic correlations across countries that were less than one (Sigurdsson et al., 1996). This indicated that differences in top-100 bull listings were expected, as Interbull evaluation became available for an increasing number of traits, and broader selection indices were developed in various countries.

Most countries use minimum requirements based on reliability, semen availability, and number of daughters and herds to exclude bulls from officially published top-100 bull rankings. Values above diagonal in Table 3 include number of common bulls among top-100 bull listings without restrictions for those countries that did use such requirements (Australia, France, Germany, Ireland, Italy, Japan, New Zealand, Spain, and the United States). Number of common bulls increased for most country pairs, especially involving Australia, Italy, Japan, and Spain without restrictions. Restrictions on top-100 bull lists might have an impact on realized genetic gain, as some high-ranking bulls may be excluded from official listings, thereby lowering the selection differential. However, this negative impact might be offset by use of higher reliability bulls with more accurate proofs than newly proven bulls, whose breeding values based on a small amount of daughters might be affected in some countries by the overestimated breeding values of their dam.

Over time, the number of common bulls among top listings in various countries has decreased proportionally with changes in national selection indices and availability of Interbull evaluations. When selection indices were similar across countries and Interbull evaluations were not yet available (genetic correlations among countries equal to one), the average rank correlation among top bull listings from various countries was greater than 0.88 (Leitch, 2004). When Interbull evaluations became available, genetic correla- tions lower than unity decreased the average number of common bulls among top listings for single traits, as shown in Table 2, with an average of 60 bulls in common across all 3 traits (protein yield, overall udder, and SCS). It should be noted, however, that the advent of Interbull evaluations improved the accuracy of international comparisons allowing the bulls to rank differently across countries. A small number of common bulls in top listings for selection indices for countries having 2 national selection indices (69 between PLI and TOP for Great Britain, and 54 between Net Merit and TPI for US), can be solely attributed to differences between the 2 pairs of selection indices, because genetic correlations within country were equal to one. The average number of common bulls in top listings for various selection indices (average of below diagonal elements in Table 3) was drastically lower (25) than average number of top bulls for single traits (60). This average became even smaller (18, average of upper diagonal elements in Table 3) when only official top100 listings were considered, based on restrictions applied on certain country top listings. Although farmers today have more and better information on which to base their selection decisions compared with previous decades, a low number of common bulls could create problems for AI organizations that are under pressure to have top bulls in many country rankings. Alternatively, a low number of common bulls could indicate that there are an increasing number of selected bloodlines, thus slowing down the increasing rate of inbreeding in the global Holstein population. A larger international gene pool would give dairy farmers a wider selection of top bulls that may be less related to the animals in their herd.

Although the number of bulls in common was quite low among top bull listings worldwide, a slightly greater similarity was found among the sires of those top bulls. This could be explained by the fact that bull sires partly represent historical selection decisions. The sires with the largest number of sons for each country's official listing are in Table 4. New Zealand had the lowest number of total sires (32), whereas Great Britain (both PLI and TOP) had the highest number of different sires with an average of almost 2 sons per sire. Table 4 also shows the level of similarity of sire of sons across the various top-100 bull listings. The sire with the largest number of sons in the top100 listings had 82 sons in 16 listings, present in every country listing with the exception of New Zealand.

\section{CONCLUSIONS}

Selection indices have evolved worldwide, shifting the focus on production to a more balanced breeding 


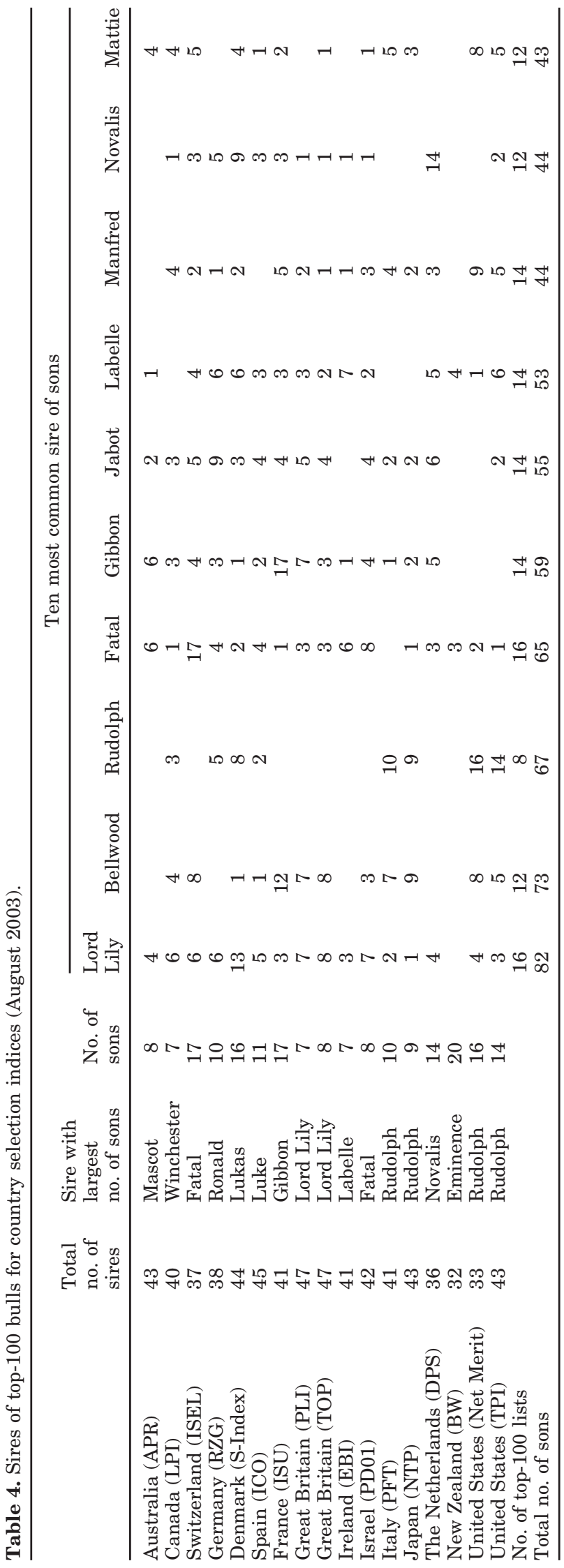

goal of improving production, especially protein yield and percentage, as well as longevity, udder health, conformation, and reproduction. Overall, the Danish S-Index had the most balanced emphasis across all components, with $34 \%$ on production, $29 \%$ on durability, and $37 \%$ on health and reproduction. The broadening of breeding goals through recent changes to selection indices decreased the similarities of top- 100 bull listings in various countries, with a slightly greater commonality among sires of top bulls. When Interbull begins providing international evaluations for longevity, calving ease, and reproduction, a slightly higher number of common bulls may be expected among those countries that do not use conversion and prediction formulas for traits that are not currently included in Interbull evaluations.

\section{ACKNOWLEDGMENTS}

The cooperation of national genetic evaluation centers and breed associations that provided information and data is kindly acknowledged. The authors would like to thank the 2 anonymous reviewers for helpful suggestions to improve the manuscript.

\section{REFERENCES}

Animal Improvement Programs Laboratory (AIPL). 2004. Subject: Inbreeding trends. Online. Available http://aipl.arsusda.gov/dynamic/inbrd/current/kindx.html. Accessed Nov. 9, 2004.

Canadian Dairy Network (CDN). 2004. Subject: Inbreeding trends. Online. Available http://www.cdn.ca/articles.htm. Accessed Nov, $9,2004$.

Goddard, M. E. 1985. A method of comparing sires evaluated in different countries. Livest. Prod. Sci. 13:321.

Haile-Mariam, M., P. J. Bowman, and M. E. Goddard. 2003. Genetic and environmental relationships among calving interval, survival, persistency of milk yield and somatic cell count in dairy cattle. Livest. Prod. Sci. 80:189-200.

Hansen, M., I. Misztal, M. S. Lund, J. Pedersen, and L. G. Christensen. 2004. Undesired phenotypic and genetic trend for stillbirth in Danish Holsteins. J. Dairy Sci. 87:1477-1486.

Harbers, A., L. Segeren, and G. de Jong. 2000. Genetic parameters for stillbirth in The Netherlands. Interbull Bull. No. 25:117-122.

Heringstad, B., Y. M. Chang, D. Gianola, and G. Klemetsdal. 2003. Genetic analysis of longitudinal trajectory of clinical mastitis in first-lactation Norwegian Cattle. J. Dairy Sci. 86:2676-2683.

International Bull Evaluation Service. 2003a. INTERBULL routine genetic evaluation for production traits, November 2003. Online. Available http://www-interbull.slu.se/eval/nov03.html. Accessed Dec. 9, 2003.

International Bull Evaluation Service. 2003b. INTERBULL routine genetic evaluation for conformation traits, November 2003. Online. Available http://www-interbull.slu.se/conform/ cnov03.html. Accessed Dec. 9, 2003.

International Bull Evaluation Service. 2003c. INTERBULL routine genetic evaluation for udder health traits, November 2003. Online. Available http://www-interbull.slu.se/udder/unov03.html. Accessed Dec. 9, 2003.

International Bull Evaluation Service. 2004. Policies regarding national and Interbull evaluations. Online. Available http://wwwinterbull.slu.se/polic_release/table2-041.html. Accessed Nov. 11, 2004. 
Kadarmideen, H. N., R. Thompson, M. P. Coffey, and M. A. Kossaibati. 2003. Genetic parameters and evaluations from single- and multiple-trait analysis of dairy cow fertility and milk production. Livest. Prod. Sci. 81:183-195.

Kearney, J. F., E. Wall, B. Villaneuva, and M. P. Coffey. 2004. Inbreeding trends and application of optimized selection in the UK Holstein population. J. Dairy Sci. 87:3503-3509.

Klei, B., K. Weigel, and T. Lawlor. 1999. MACE: the relative importance of information source. Interbull Bull. No. 22:9-13.

Leitch, H. W. 1994. Comparison of international selection indices for dairy cattle breeding. Interbull Bull. No. 10.

Meyer, C. L., P. J. Berger, K. J. Koehler, J. R. Thompson, and C. G. Sattler. 2000. Interactions among factors affecting stillbirths in Holstein Cattle in the United States. J. Dairy Sci. 83:2657-2663.
Miglior, F. 2000. Impact of inbreeding: Managing a declining Holstein gene pool. Pages 108-113 in Proc. 10th World HolsteinFriesian Conf., Sydney, Australia.

Schaeffer, L. R. 1994. Multiple-country comparison of dairy sires. J. Dairy Sci. 77:2671-2678.

Sigurdsson, A., G. Banos, and J. Philipsson. 1996. Estimation and genetic (co)variance components for international evaluation of dairy bulls. Acta Agric. Scand. 46:129-136.

VanRaden, P. M. 2002. Selection of dairy cattle for lifetime profit. Pages 127-130 in Proc. 7th World Congr. Genet. Appl. Livest. Prod., Montpellier, France.

Veerkamp, R. F., E. P. C. Koenen, and G. De Jong. 2001. Genetic correlations among body condition score, yield, and fertility in first-parity cows estimated by random regression models. J. Dairy Sci. 84:2327-2335.

Wilmink, J. B. M., A. Meijering, and B. Engel. 1986. Conversion of breeding values for foreign populations. Livest. Prod. Sci. 14:223. 